\title{
Analysis of Prioritization of the Influencing Factors on Investment and Muscle Drain in Volleyball Clubs in Developing Countries. Case Study: Premier League Club of Iran Volleyball
}

\author{
Atefeh Saki ${ }^{1}$ \\ ${ }^{1}$ Master of Project Management, University of Wollongong, Australia \\ Correspondence: Atefeh Saki, Master of Project Management, University of Wollongong, New South Wales, \\ Australia.
}

Received: January 18, 2016

Accepted: February 5, 2016

Online Published: February 29, 2016

doi:10.5539/mas.v10n3p191

URL: http://dx.doi.org/10.5539/mas.v10n3p191

\begin{abstract}
Present study pays to prioritize influencing factors on investment and muscular analysis in volleyball club in developing countries. The research method is descriptive and practical. Territory of study is spring and summer 2015 and statistical population is Iran's national volleyball team. The number of community members is 36 that were selected 36 persons as members with using the census. Two questionnaires were used to collect data. The first questionnaire was used for getting comments of coaches and technical staff and the second questionnaire was used for getting players comments. Validity was approved by athletic and academic experts and reliability was approved with Cronbach alpha coefficient. The rate of questionnaires returns was $100 \%$ and the number was 36. The results indicate that coaches and technical staff believed that the impact of investment income on the sports club of volleyball is more than the cost effectiveness of it and the players comment is that health is a priority in relation to other criteria.
\end{abstract}

Keywords: investment, muscle wasting, volleyball

\section{Introduction}

Over the past two decades the mechanisms of privatization have been designed and implemented as a solution in many countries and is used it as a solution in order to rationalize the economic structure of society, reduce the financial burden, increase efficiency, expand its activities and the efficient use of facilities and resource utilization. Privatization like many other policies is including social, political and economic ways, and the most important objectives of it is the decentralization of the economy and engage more people in productive activities, and improve service and achieve higher levels of economic growth (Nasirzadeh, 2010). Research has shown that productivity and profitability of private firms is higher than government agencies. Ahrlich (1994) believes that state ownership decrease productivity growth rate and increase the rate of cost.

\section{Investment}

The prevailing opinion about exercise is as a consumer spending among people of some communities and they are ignored its importance in the production and economic growth and better income distribution. As the pay attention to the exercise requires the high cost of infrastructure, but these costs cannot be placed on the side of spending and consumer spending. Today as proportion that is spent on exercise in some sports in the short term and in another in the long term you can see the return on investment directly and indirectly. Following the investigation in exercise is increased direct and indirect employment and along it will be increased the possibility of attracting income through international competitions, attracting tourists and the level of physical and mental health. The main obstacle in the process of investing in countries sport is the lack of visible return benefits of this investment as directly. While a positive attitude to sport and side of it are awarded more profits as directly or indirectly, in the future. There is a positive attitude towards sport in modern society, due to has investment in sport to raise the level of health and the impact on the increase in productivity and this has gradually led that the most of the countries that previously were not given much to contribute increasingly to invest in the sport of reprisals. So the budget has been increased with unprecedented speed for physical education and sport in developed countries and some developing countries. Hence these countries have been aware about long-term effects of the development of the national economy. Sport has a long-term investment that is clear and obvious 
its effect on growth and development. Investment in sport is including investment that has both short-term and long-term periods that by addressing it can be achieved the remarkable socio-cultural and economic outcomes and try to solve the needs of society and the national welfare (Mahmudi, 2015).

Today the exercise has become change of a recreational activity to recreation industries that is booming and profitable, so that in developed countries, big money to be goes into this profitable industry as it as profitable part. Countries such as Germany achieve a significant proportion of its GDP through investment in the sports industry and sport economic prosperity. In the 90s, the sport was known as seventeenth superior industry known in terms of turnover in the United States of America, but now it is known as the fifth best industry in this country by the huge investment that made by the government and the private sector. Sports industry is the biggest financial industry in this country with turnover of 252 billion dollars after the sale of the property, the computer industry, health and defense industry. To clear this case it is necessary to point out that this industry can pass some industries in terms of turnover such as the automotive and engine industry and even surpass Hollywood in America (Mahmudi, 2015). Unfortunately, the club owned by the government it is difficult identifying revenue and cost and profitability analysis because of corruption and a lack of oversight possible and consequently the ROI. Whereas, should be properly identified and correct analysis of the return on investment in clubs to encourage investors to invest in the sports industry revenues and expenses, so investors are encouraged to participate in clubs with less risk.

\section{The benefits of investing in the sports industry}

\section{$\checkmark$ Direct and indirect job creation}

The most important benefits of investing in the sports industry is creation direct and indirect employment. For example, now many people are working in sports teams as a player, coach, manager, doctor, etc. This can be one of the best examples of direct employment in the sports industry. In addition to creating sports infrastructure required to build stadiums, venues and sports facilities that it can be provided many job fields for jobseekers (World Economy, 2015).

\section{$\checkmark$ Reduce crime}

By accepting the assumption that the increasing sportsmanship in the society to reduce the risk of crime in the society, it can be concluded that investment in the development of sport, much more needs to cost and is very effective and more efficient investment in fighting and preventing crime. With increased investment in sport in disadvantaged areas can attract young people in these the areas to sports, and strengthened in them sportsmanship and the possibility of reduced crime in society (World Economy, 2015).

\section{$\checkmark$ Attract sport tourists and earn money}

By investing in sports and present international tournament can be used to attract foreign tourists and by this way the owner achieve huge revenue. For example, in 2002 Japan and South Korea held their football World Cup. While this event happened in two countries that Korea and Japan were faced with relative economic decline and a decrease of national revenues. The done investments by these two countries were about $\$ 10$ billion to host this major sporting event, the amount. By attention to the estimation of South Korean government that the benefit of this country at the end of tournament spectators and tourists arriving to sell a football fan was about twenty billion dollars. Like this event was held in 2006 in Germany and the country was able to attract sports tourists from around the world and is own around 11 billion dollars is won. These benefits are all the result of investment in sport (World Economy, 1394).

\section{$\checkmark$ exports of goods and sport services}

Investment in the sports industry provide production growth and export goods and sport services. Brazil and Argentina are the two countries in the field of sports services exports to the transfer of sports players especially in football in other countries that these countries have large incomes of foreign exchange. Also, with the growth of the sports industry will be grown sports shoes and apparel manufacturing plants, and by selling its products to clients, to gain huge profits. For example, Puma is a German company that now is considered one of the largest manufacturers of shoes and sports apparel. With the growth of the sports industry in the world and increase the amount of clothes and shoes, the company in 2007 gained two billion and three hundred and seventy-three million euro net profit (World Economy, 2015).

$\checkmark$ Improving the health and well-being in the community

Positive attitudes in community towards exercise, due to investment in sports, and this is providing the increases in health and wellbeing of individuals. Health of human resources is due to increase productivity levels and will 
bring the national economy growth in long term. Listed items are just some of the benefits of investing in the sport industry. What can be stated with certainty invest in the sports industry not only cost, but also it will have huge profits for investors in short and long term. It can even be said that investment in the sports industry have benefits in terms of social, cultural and political for society as well. Perhaps what thing that is a barrier for investors from investing in this lucrative industry is anonymity benefits of investing in sport (World Economy, 1394).

\section{Privatization}

Privatization is considered in all industries and the sports industry is no exception from this category. Today, scholars argue that the proper way to deal with difficult economic conditions that surround the sports industry is privatization and participation the private sector in sports. According to this the traditional structure of the club has been changed in many countries and clubs thanks to the commercialization of the sport industry (Michic, 2004). Today, in developed countries, the added value of the sports industry is a significant part of gross domestic product and it has important role in income generation, employment and recreation and entertainment (Holt, 2007).

There are some problems for privatization in developing countries as follow

1. The high cost of construction and purchase of sports facilities and sports equipment;

2. Inadequate public facilities;

3. The unwillingness of people to pay money for exercise,

4. Lack of financial ability of people to use the services of the private sector,

5. Lack of suitable culture media and radio and television advertising and on participation the private sector in the exercise,

6. The lack of regard for appropriate pricing of private club services;

7. Lack of investment security in the short and long term;

8. Unpleasantness labor law, insurance and tax laws mar- government agencies; management problems and security, private clubs (Ahmadi et al., 2006);

9. Inability to identify transferable places, deselect the appropriate financial consult,

10. Lack of bank loans with low interest and a lack of specific legal and administrative facilities of the Department of Physical Education,

11. Lack of proper performance of private sector investment in sport;

12. Not fast enough to grant facilities Licensing and development of sport facilities by municipalities map (Aghayee, 2006),

13. Lack of rule of logic, the cost - benefit of professional football clubs,

14. The lack of privatization methods that available for selecting the most effective method for transferring clubs,

15. Lack of development and implementation of the development, management, maintenance and development of professional clubs;

16. The use of scientific methods for pricing tickets (Elahi, 2009);

17. Limitations of the legislative and regulatory environment;

18. A lack of overall planning, lack of recognition and lack of suitable and affordable in the private sector,

19. Underestimating the serious presence and activity of the private sector in the exercise of governmental organizations,

20. The lack of accurate statistics and information of existing sport facilities (Razavi, 2005);

21. The lack of definition of the private sector and non-governmental,

22. Poor performance of organizations,

23. Institutions and agencies competent in the field of promotion and development of sports culture as a commodity essential part of household which would lead to conduct some cost to exercise;

24. Not having the necessary infrastructure, such as electricity, water, telephone, 
25. Infrastructure, landscaping and so on for the private sector that imposes enormous costs on the private sector,

26. Lack of transparency in contracts and the lack of property rights (AzizNezhad, 2008),

27. Lack of technical expertise and training sport education (practical and scientific), and experienced and knowledgeable in the management of the municipal sports facilities,

28. The loss of incentive to compete in the rich, donors and benefactors, especially in cooperation with municipalities in the construction of sports facilities (Bahram Nezhad 2008);

29. Inefficiencies and flaws in the market system and the lack of an efficient private sector,

30. Political and ideological beliefs and values of the country economy (Komeyjani et al., 1997),

31. Lack of creativity and entrepreneurship and prepare the private sector for risk and knowledge of wide management organization (Paygozar, 2008),

32. The lack of substantial savings in domestic capitalists;

33. Lack of attention to the problem of unemployment, while employment in the private sector is a necessity in developing countries,

34. Use of corporate and government agencies in addition to policy investment, as an important and significant institution through the development and public policy, Private sector decision-making based on market prices and the lack of attention to the real needs of society (production of more profitable luxury goods instead of production of essential goods) (Davarzani, 1995);

35. Unstable and uncertain national economy, political uncertainty about privatization,

36. Against interest groups that benefit from government control over economic activity,

37. Weak financial markets, delays and bureaucratic complexity,

38. Lack of management skills in a market economy,

39. Uncertainty rules and defective title, restrictive laws and high taxes,

40. Public antipathy towards private entrepreneurs,

41. Vague objectives, multiple and contradictory,

42. Lack of motivation in management levels,

43. Decision-making is too centralized, resistance against privatization of public sector employees and managers,

44. Avoid domestic and foreign investors in privatization programs;

45. The unwillingness of political leaders to privatization programs (Monavarian, 2002).

46. A high-risk for making sport facilities (Frybote, 2007);

47. High cost of building stadiums,

48. Sports grounds and other places related (Alexander, 2000),

49. Lack of specialized institutions in the private sphere of the sports industry.

\section{The role of player as an intangible asset}

Some methods of valuing human resources include:

- economic value (current value)

- valuation method of random bonuses

- replacement value

- Theory of auctions

- coefficient value

- $\quad$ historical cost

With investigation of the clubs in developed country can be found that with by attracting private investment and encourage private firms to invest in clubs can be compensated a lot of problems mismatch between costs and revenues. 


\section{Defining of human resource accounting}

According to the definition of America accounting community of human resources, the detection process and measurement of this information is about and the information reports is for parties and stakeholders. In fact, accounting of human resources is the formation of the quality and quantitative content of human resource value with basic knowledge of accounting and so it including identification of quantity and quality of it, assessment and measurement of the economic value and the appropriate financial reporting.

\section{Needs and goals of human resource accounting}

Today, most organizations can get detailed information about its tangible assets, such as land, buildings, machinery and equipment but usually they are not official record of their intangible assets such as trademarks for spending on research and development of human resources that create increasing value for the organization.

So the lack of information about the economic value of the organization's human assets or done expenses is as weaknesses of the current accounting system e for education and training of qualified personnel and the amount of the lost cost. Todays the importance of human capital in firms is equal natural equipment. The value of human resources is very important as an asset especially in sports clubs, In fact, it can be stated that human resources are the most important asset a club sport club that is invaluable and due to this type of asset and the lack of shared risk and diversification, and the depreciation of such assets should be investigatef the value of human resources at the club as properly.

\section{The amount of organization investment in human resources}

Many organizations spend significant amounts of money for staff training programs without evaluating the return on investment and evaluation of the results as accurately and even in the event of failure to pay is stopping a training program. So with considering the necessity of separating the real costs of other expenses in connection with the human resources of the entity must be distinguished between the current costs of capital of manpower. Because it information enables management to adopt a decision making based on the cost of the capital gain.

\section{Increase the efficiency of human resource management}

Accounting of human resources is a combination of accounting and human resource management. The application of accounting methods and concepts and the use of technology and pattern measurement can be a profound influence on the running of the organization.

\section{Muscle drain}

Atrophy of the muscles causes reduces the size, strength and mobility of the muscles of the body. Cells in response to changes in their environment can change their own. Atrophy is one of these answers. In one definition can be said reduction the size of cell due to loss of cell content is atrophy. Atrophy of muscle means lean and weakening muscles. Muscle atrophy can be followed by decreased blood flow to the muscle or paralyzing of muscle nerves or not use long-term of muscle. Once a certain number of cells are involved organ, the total organ or tissue is small and occuracne atrophy, so should be emphasized that although performance may be reduced the atrophic of cells, but these cells are not dead cells (Sajjadpour, 2015).

As the name show that the muscle drain related the age will be occur by aging but sedentary lifestyle increases the risk of this disease.

Other causes of this illness are include amyotrophic lateral sclerosis, burns, dermatomyositis, poly myocytes, Guillain-Barre syndrome, physical injuries, long-term treatment with corticosteroids, poor nutrition, diabetic nephropathy, muscular dystrophy, immobility, osteoarthritis, polio, arthritis, spinal cord injury and stroke.

\section{Types of muscular atrophy}

\section{$\checkmark$ Atrophy due to the lack of long-term use of muscle}

In most people, muscle atrophy occurs due to inadequate use of muscles. People who are sitting jobs, people who are ill and have less movement, can be reduce their muscle size and weaknesses. This type of atrophy can be corrected with exercise and proper nutrition. People who are hospitalized, they will have the most muscular atrophy. Astronauts that away from Earth's gravity will be lose muscle contraction after a few days of weightlessness (Sajjadpour, 2015). In the sport dimension, non proper use and regular performance of athletes of bodybuilding muscles will be caused muscle wasting in the athletes.

\section{Atrophy caused by paralysis of motor neuron}

When an injury or illness hits connected nerve to tissue occurs nerve atrophy. This atrophy occurs suddenly. Diseases that affect the nerves of muscles including: 
- Amyotrophic lateral sclerosis: it is the disease of nerve cells in the brain and spinal cord that control voluntary muscle movement.

- Guillain-Barre syndrome: in this disease the immune system attacks the nervous system wrongly.

- Neuropathy (disease or bad performance of nereve)

- Polio: a viral disease that affects the nerves and can lead to paralysis part of the body or the whole body.

Although people can cope with muscle atrophy, but even mild muscle atrophy caused the power loss and reducing body movements (Sajjadpour, 2015).

\section{History Research}

Shahbandzadh (1993) considered avoiding of creating multiple centers of management and leadership in the privatization process when creating the new structure.

Ahmadvand (1995) believes that the organizational transition in the privatization process should be based on clear objectives and follow a certain pattern

Heydari (1997) believes that in the model of privatization should be considered ownership; improve the management, control, guidance, expertise and continuous monitoring. Khosh Khabar (1997) says about investigated the effects of privatization in Physical Education Organization that the public sector should lead to greater efficiency and productivity with giving the more divestiture of sports facilities.

Razavi (2004) emphasizes on implementing the privatization program in sport and believes that sport should be transferred from focus on the public sector to the private sector (NOC).

Afarinesh Khaki and his colleagues (2005) say that one of the ways of development of mass sports are leaving it to the private sector.

Arefian (2005) reviewed the privatization in department of physical education in the Mazandaran province and understand that privatization leads to enhanced productivity and optimization of the sport in this province.

Shamsaie (2009) reviewed the status of private in clubs and said that privatization in this club is to improve the employment situation.

Keshkar et al (2011) reviewed the results of the privatization program in sports assets and they showed that competition, financial interests and profitability, performance, evaluation and monitoring, serve the interests of consumers, the use of expertise rather than before privatization had improvement and deregulation, employment and wages, property development are unchanged.

Mozangaza et al (2001) said that the structure of the new requirements was inconsistent with realism and so it caused the slow action in implementation of the government's operations.

\section{Goals}

Prioritization of the influencing factors on investment and muscular analysis of volleyball clubs in developing countries

\section{The innovative aspect of this research}

This study is creative that is currently considering the issue of library research and field work in a developing country that is not done in national volleyball team.

\section{Research Methodology}

This study is applied, descriptive - survey. Territory of study is spring and summer 2015 and statistical population is Iran's national volleyball team. The number of community members is 36 that were selected 36 persons as members with using the census. Two questionnaires were used to collect data. The first questionnaire was used for getting comments of coaches and technical staff as follow:

Table 1. Correspond to the first questionnaire

\begin{tabular}{llc}
\hline row & component & Number of question \\
\hline 1 & physical abilities & 5 \\
2 & physical condition & 7 \\
3 & Awareness of the environment around the Earth & 9 \\
4 & Terms of transcendent players & 3 \\
\hline
\end{tabular}


Table 2. Correspond to the second questionnaire

\begin{tabular}{llc}
\hline row & component & Number of question \\
\hline 1 & The impact of income investment & 9 \\
2 & The impact of cost on investment & 6 \\
\hline
\end{tabular}

Validity was approved by athletic and academic experts and reliability was approved with Cronbach alpha coefficient in SPSS software is as follows:

Table 3. The reliability of the first and second

\begin{tabular}{cl}
\hline $\begin{array}{c}\text { Cronbach alpha } \\
\text { coefficient }\end{array}$ & \multicolumn{1}{c}{ variables } \\
\hline $0 / 874$ & $\begin{array}{l}\text { Comment players about the affecting factors on investment } \\
\text { Comments of managers, coaches, administrators about the affecting factors on } \\
\text { investment } \\
\text { The reliability of the questionnaire }\end{array}$ \\
$0 / 894$ & . \\
\hline
\end{tabular}

\section{Data Analysis}

\section{Described the sample by gender}

Table 4. Sex OF subjects

\begin{tabular}{lll}
\hline Percentage & Frequency & Variable \\
\hline $\mathbf{0}$ & $\mathbf{0}$ & female \\
$\mathbf{1 0 0}$ & $\mathbf{3 6}$ & male \\
100 & $\mathbf{3 6}$ & total \\
\hline
\end{tabular}

According to the table $0 \%$ of subjects are female and $100 \%$ are.

Described the sample according to educational level

Table 5. Education level of subjects

\begin{tabular}{lll}
\hline percentage & frequency & variable \\
\hline $\mathbf{2 5}$ & $\mathbf{9}$ & Diploma and lower \\
$\mathbf{6 1 . 1}$ & $\mathbf{2 2}$ & Graduate \\
$\mathbf{1 3 . 9}$ & $\mathbf{5}$ & BS or above \\
$\mathbf{1 0 0}$ & $\mathbf{3 6}$ & total \\
\hline
\end{tabular}

According to the table, $25 \%$ of participants have a lower degree and 61 percent have a bachelor's degree and 13.9 percent of respondents are highly educated graduate.

\section{Described the sample by age}

Table 6. Age of subjects

\begin{tabular}{lllll}
\hline Total & $\mathbf{4 1 - 5 0}$ & $\mathbf{3 1 - 4 0}$ & $\mathbf{1 5 - 3 0}$ & \\
\hline $\mathbf{3 6}$ & $\mathbf{1}$ & $\mathbf{1 4}$ & $\mathbf{2 1}$ & frequency \\
100 & $\mathbf{2 . 9}$ & $\mathbf{3 8 . 4}$ & $\mathbf{5 8 . 7}$ & percentage \\
\hline
\end{tabular}

$58.7 \%$ of respondent's age is between 15 and 30 years, $38.4 \%$ is between 31 and 40 years and $2.9 \%$ is between 
41 and 50 years.

Using the Kolmogorof-Smirnof test showed that there was abnormal distribution data so will be used non parametric tests.

\section{Friedman test}

To determine the priority of the respondents' views was used Friedman test. SPSS output includes the following table. This table shows the average rank of each of the relevant variables.

Table 7. Ranked players on the influencing factors on investment and muscular drain

\begin{tabular}{llll}
\hline priority & Average of ranks & dimension & row \\
\hline first & $3 / 23$ & physical abilities & 1 \\
second & $3 / 19$ & physical condition & \\
third & $3 / 01$ & Awareness of the environment around the Earth & 3 \\
fifth & $2 / 79$ & Terms of transcendent players & 4 \\
\hline
\end{tabular}

Table 8. Ranked comment of Managers, coaches, administrators on the influencing factors on investment and muscular drain

\begin{tabular}{llll}
\hline priority & Average of ranks & dimension & row \\
\hline first & $3 / 29$ & The impact of income investment & 1 \\
second & $3 / 11$ & The impact of cost on investment & 2 \\
\hline
\end{tabular}

\section{Conclusion}

In present study is pay attention to prioritize affecting factors on investment and analysis of Muscular drain return and lack of muscle discharge of Volleyball Club's in developing countries. Iran is as a developing country and is used the national team's players and staff and as a case study and as field the questions of questionnaire gave them. To respond fully to questions by respondents the researcher had physical presence and given explanations.

The analysis of the answers to questionnaires was tested and then is done the analysis of the influencing factors on investment and muscle and with notice to being abnormal data is used the Friedman nonparametric test to prioritize. The results of the questionnaire showed that physical condition was the highest priority and transcendent of players is the lowest priority for the contract and determined players wages (as Price Club).The results of the staff questionnaire (managers, coaches, and administrators), shows the impact on investment income is higher than the effectiveness of the cost of the investment due to direct and indirect revenue.

Reaction speed, jump and jump, muscle coordination, index of injury, mental and spiritual capabilities, age and the height of volleyball player would be willing an investor in the private sector $g$ to maneuver on the athlete and so he is as a motivating factor for investments. Also the physical abilities like the running, speed, stamina, balance and strength could also be a lead investor to invest on athletes, but these abilities are less important than physical condition. For posts such as defense and faster, height and speed can be a decisive factor. To post of setter the awareness around Earth can launch point is to capitalize on the athlete. Player's transcendental conditions can be considered as a brand and a competitive advantage for an athlete, by which their, the investor can market through brand and name of players and clubs and through this type of extensive and effective advertising making revenue.

The questionnaire was made available to staff and the forces were analyzed. The income rate from the investment as revenues from ticket sales, sponsors and etc are higher priority than the cost of the players, the technical staff and the respondents.

Investment in sport is a win-win proposition.

Profit for investment through advertising and income as following methods:

- ticket sales and licensing of media player

- Setting up schools and institutions

- participation in large projects

- invest in various projects from the revenues of club 
- Using tax breaks and corporate social responsibility performance

- The use of state material and immaterial benefits resulting from participation in clubs

- $\quad$ entrance the free investment in sports

- optimal using of players with suitable income for the future guaranty and consequently the more development of clubs and players earn

\section{Suggestions}

Players was recorded as an intangible asset on the balance sheet in clubs until the investor can see the feedback of invest in players as positive and with anticipated the costs and revenues is determined her expected returns and be fertile the incentive to invest in him,and the type of contract and earning of player, according to predetermined principles and criteria is used for the identification and review and analyze the other hand, revenues club.

Estimation of the useful life of each player in each position is achieved by average of useful life.According to their useful life and depreciation, income and amount of the contract is the way that he motivated players in domestic leagues has enough material to work. Unfortunately, due to the wage gap in domestic leagues and leagues privately owned foreign countries, including non-sports players motivated by economic factors or acquiring citizenship of another country are decided to switch to foreign leagues and even lower in some countries (wladimier Andreff,2010).

In fact, it can be said that if the player except sporting reasons other than professional development and gain experience and material reasons he decided to transfer to other country at the age of the peak of energy and standard for play them. When the player will be returned the country suffered from muscular dystrophy and amortized This is an example of the brain drain in the social science that can be as muscles drain in the sport, which in recent years have occurred in developing countries. In the case of right and reasonable investment in sport the investment can achieve expected return by earn money and athlete will be exercise with reasonable income and more energy in the local club and his country.

\section{References}

Ahmadi, A., Mohammadzade, H., \& Tartibian, B. (2006). The obstacles and problems in the privatization exercise from the perspective of owners of private clubs in Oromiye city. Proceedings of the National Conference of Sports, Physical Education Tehran Municipality. Pp: 6-7.

Andreff W. (2008b), The Economic Effects of the Muscle Drain. In G. Walters, \& G. Rossi, (Eds.), Labour Market Migration in European Football: Key Issues and Challenges. Conference Proceedings from the Feet-Drain Conference hosted by the Birbeck Sport Business Centre in May 2008. Birbeck Sport Business Centre Research Paper Series, 2(2), 8-30.

Andreff, W. (2006). International labour migration, in W. Andreff\& S. Szymanski, eds., Handbookon theEconomicsofSport, Edward Elgar.

Andreff, W. (2010). Muscle drain in sport and how regulate it? A plea for a Coubertobin tax.Second GDRI-DREEM International conference, Cario.

Aziz Nezhad, S. (2008). Barriers to investment in sport and ways to attract private sector participation. The second set of papers for the development of the cultural investment conference in Tehran (challenges and opportunities), the exercise of Tehran, pp. 15-52.

Bahramnezhad, Z. (2007). A comparative study of the privatization process in Russia. China, India, Bolivia, Poland, Brazil. Privatization world, 6, 42-48.

Davarzani, M. R. (1995). The effect of privatization on efficiency and effectiveness of the exercise. PhD thesis, Faculty of Tehran University. Pages: 1-18.

Elahi, A. R. (2009). Barriers to attracting revenue from sponsorship in the football industry Islamic Republic of Iran. Sport Management, the first issue, summer. Pages: 189-202.

Holt, M. (2007). The ownership and control of elite club competition in european football. Soccer and Society, $8(1), 50-67$.

Komijani, A., \& Khoosh, P. H. (1997). Theoretical foundations and causes the formation of public companies privatization plan (goals legal process). Research and economic policies, 7, 43-64.

Michic, J., \& Oughton, C. (2004). Competitive balance in football: Trends and effects. FGRC research paper, No. 
2, Birkbeck, university of London. Retrieved from http://www.bbk.ac.Uk/ hosted/management/msemres/oldfootballsite1/papers/competitivedbalance-paper.htm\# what

Monavarian, A. (2002). Privatization: A Comparative Approach. Quarterly management process and development, 53 and 54, 47-67.

Paygozar, N. (2008). Test health, Proceedings of the Second International Conference to develop the cultural capital of Tehran (challenges and opportunities). Sports Organization of Tehran Municipality, pp: 253-255.

Razavi, M. H. (2005). Privatization and Efficiency in sport. Journal of motion, 23, 5-22.

Wu, X. R., \& Hu, X. (2007). Consideretaion of privatization management of public sport facilities. Journal of hubei sport science, 26, 10-13.

\section{Web References}

http://www.donya-e-eqtesad.com/news/762095

http://www.emodiran.com/downloads/management/509

http://www.tebyan.net/newindex.aspx?pid=236020

\section{Copyrights}

Copyright for this article is retained by the author(s), with first publication rights granted to the journal.

This is an open-access article distributed under the terms and conditions of the Creative Commons Attribution license (http://creativecommons.org/licenses/by/3.0/). 